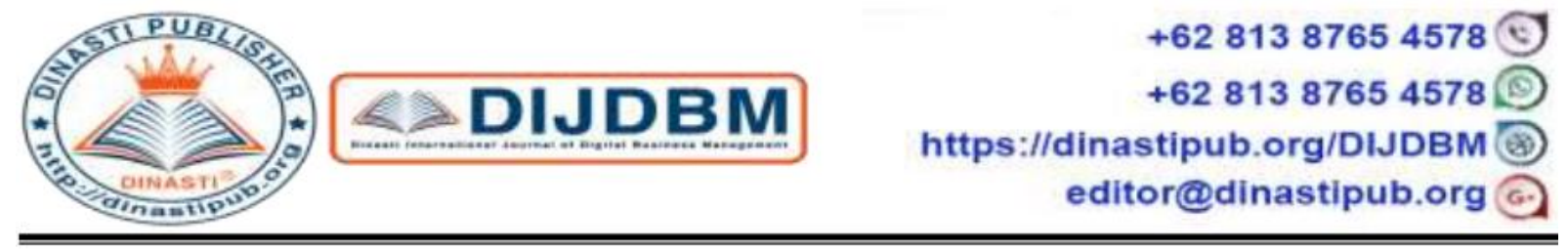

\title{
E-COMMERCE AS A TECHNOLOGICAL INNOVATION STRATEGY OF ENTREPRENEURS IN BANDUNG TO INCREASE SALES IN DIGITAL ERA
}

Nining Harnani ${ }^{1)}$, Rudi Suprianto Ahmadi ${ }^{2)}$, Nana Suhana ${ }^{3)}$, Luthfi Setiadiwibawa ${ }^{4)}$

${ }^{1,2,3,4)}$ Faculty of Economics and Business Turangga No. 25 Bandung

\begin{tabular}{|c|c|}
\hline $\begin{array}{c}\text { ARTICLE INFORMATION } \\
\text { Received: } 20^{\text {th }} \text { March } 2020 \\
\text { Revised: } 20^{\text {th }} \text { April } 2020 \\
\text { Issued: } 30^{\text {th }} \text { April } 2020 \\
\text { Corresponding author: Nining } \\
\text { Harnani } \\
\text { E-mail: } \\
\underline{\text { niningharnani@gmail.com }} \\
\underline{\text { rudiahmadi64@gmail.com }} \\
\underline{\text { sahirabuana@gmail.com }} \\
\underline{\text { setiadiwibawa@gmail.com }}\end{array}$ & $\begin{array}{l}\text { Abstract: The purpose of this research is to investigate } \\
\text { how e-commerce can increase sales volume in the } \\
\text { creative food and beverage industries. The data used in } \\
\text { this research is quantitative data from the sources; } \\
\text { whereas the primary data is gathered through } \\
\text { questionnaires, interviews and observations. } \\
\text { Furthermore, to complete the data, the author also } \\
\text { reviews documents from relevant government agencies, } \\
\text { journals, books and other references from the Internet as } \\
\text { secondary data. The method used in this research is } \\
\text { descriptive verification. The type of research is } \\
\text { descriptive verification. The study is conducted to test } \\
\text { the effect of e-commerce on sales volume by using } \\
\text { simple linear regression. Then to determine the effect, } \\
\text { the writers use the formulas of Correlation and } \\
\text { Coefficient of Determination. The results show that e- } \\
\text { commerce has a significant effect on sales volume by } \\
56 \% \text {. While the remaining } 44 \% \text { is influenced by other } \\
\text { factors outside the focus of this study. } \\
\text { - } \\
\text { Keywords: sales volume, Tecchnological Innovation, e- } \\
\text { commerce }\end{array}$ \\
\hline
\end{tabular}

\section{INTRODUCTION}

The phenomenon of change and technological development nowadays makes innovation absolutely necessary in various dimensions of life. The business world cannot be separated from the economy in a country. The role of entrepreneur is very big in increasing economic growth. At present, technology is developing very rapidly and rapidly, so that it impacts on various aspects of life in society, one of which is in the business world itself. This causes an entrepreneur or entrepreneur must have innovation, especially in technology as one of the strategies to increase sales results today. 
Innovation and entrepreneurship in the business world is one of the opportunities in society to increase economic growth, especially in job creation. In Fontana (2011) states that innovation is an economic success thanks to the introduction of new ways or new combinations of old ways of transforming input into output which creates a major change in the relationship between use value and the price offered to consumers and / or users. Expansion of definition: innovation is an economic and social success thanks to the introduction of new ways or new combinations of old ways of transforming inputs into outputs which create major changes in the relationship between use value and prices offered to consumers and / or users, communities, societies, the environment.

Humans have now experienced a concept shift towards digital native in which all activities using multimedia as a medium for communicating all forms of manual printing have gradually begun to shift as information and communication technology develops. And this is what triggers every human being to increasingly compete to find solutions to be more effective in solving everyday problems quickly. Technology that is currently unavoidable is the use of the internet in society in various aspects of life. the development of the internet and the web has changed various concepts and propositions and innovations in business, in other words the development of the internet can make changes and innovations on a large scale in making business innovations that can reduce marketing and manufacturing costs, storage, and very easy to convey to Public.

On the internet, various communities can be seen and utilized as an appropriate model in service marketing and communication with virtual concepts and portals and 24-hour access to communicate and distribute digitally which makes this system will be the desired model in the coming years.

Website or commonly called website or www and commonly referred to as site is a collection of web pages that can be accessed using http on the internet. According to Ali (2008) "Website is a place that allows a person to declare himself, his hobby is knowledge of the products he sells and anything that includes information can also be accommodated by written text, images, videos, animations and other multimedia files".

As an example of the current trend in society today is an online buying and selling system on the Internet that makes it easy for shoppers to access 24 hours nonstop. Where buyers from any region can access this system. Select the desired item and perform payment transactions then the goods are sent. Until finally the goods arrived at their destination. This term is often called ecommerce. Electronic Commerce (E-Commerce) in general is a business activity (commerce / trade) or services that are closely related to consumers (Consumers), Manufacturing,

The internet is a form of technology that has a profound influence on various aspects of life, including the business world. In Indonesia is the 5th largest internet user in the world, this in the high growth of internet users is also offset by the high mobile phone owners that is equal to 91 percent of Indonesia's population. While smartphone users accounted for 47 percent. This can be an opportunity for entrepreneurs or entrepreneurs in Indonesia to market their products in the wider community by using technology on the internet, namely using e-commerce media. 


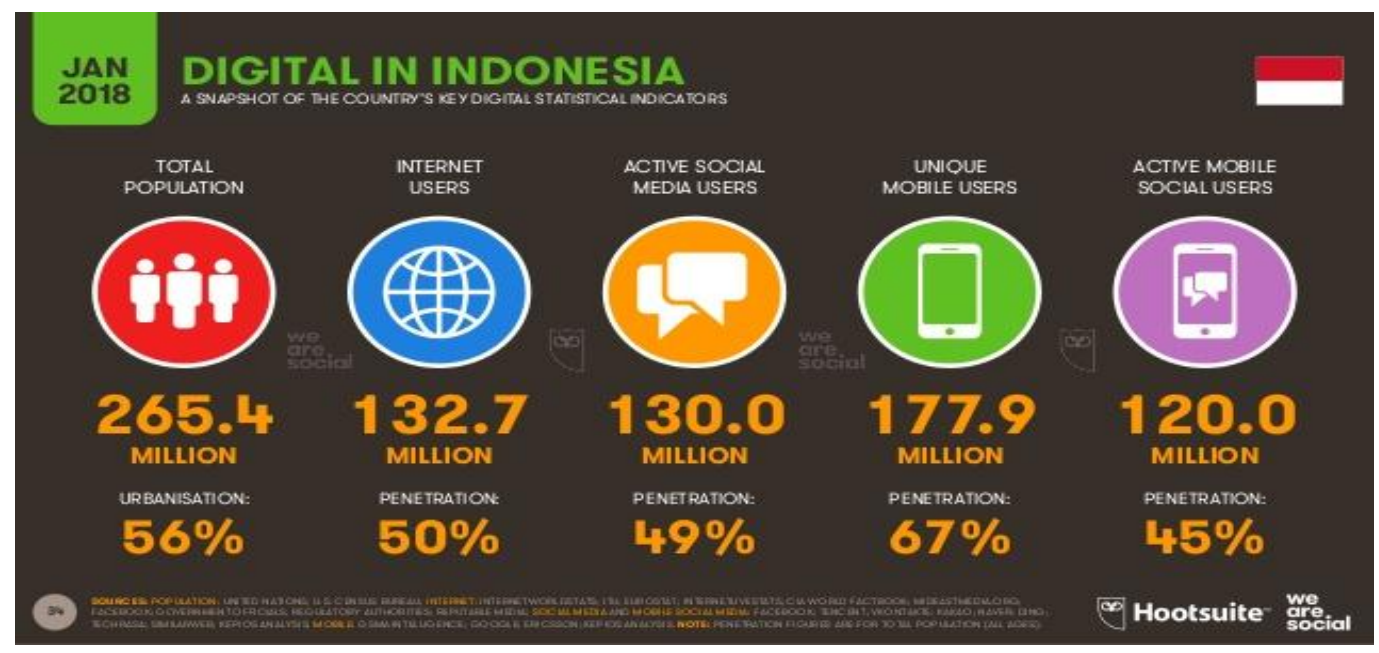

Picture 1. Internet users in Indonesia in 2018

Based on the survey results above regarding the level of digital usage in Indonesia, it can be seen that $50 \%$ of Indonesia's population are internet users in the amount of 132.7 million people, of which 130 million are active users in social media, while $67 \%$ or around 177, 9 million souls are mobile internet users or active smartphone users while $45 \%$ or as many as 120 million souls are active mobile social media users. One concrete example of the effects of the digital age is the emergence of e-Commerce which has begun to replace the normal Commerce process. Dozens of e-commerce models have emerged in Indonesia such as Zalora, Lazada, Elevania, OLX, TokoPedia, and others.

\section{Mobile E-commerce Shopping Apps with the most Monthly Active Users in Southeast Asia \\ Top E-commerce Shopping Apps* by Combined iPhone and Android Phone Averaged Monthly Active Users, Q1 2019 in Selected Countries (Indonesia, Malaysia, Philippines, Thailand, Vietnam, and Singapore)}

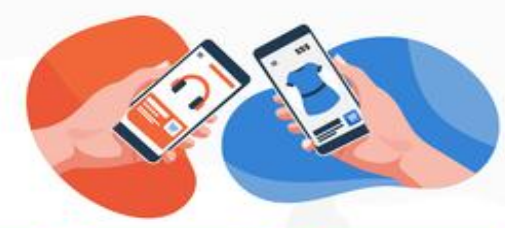

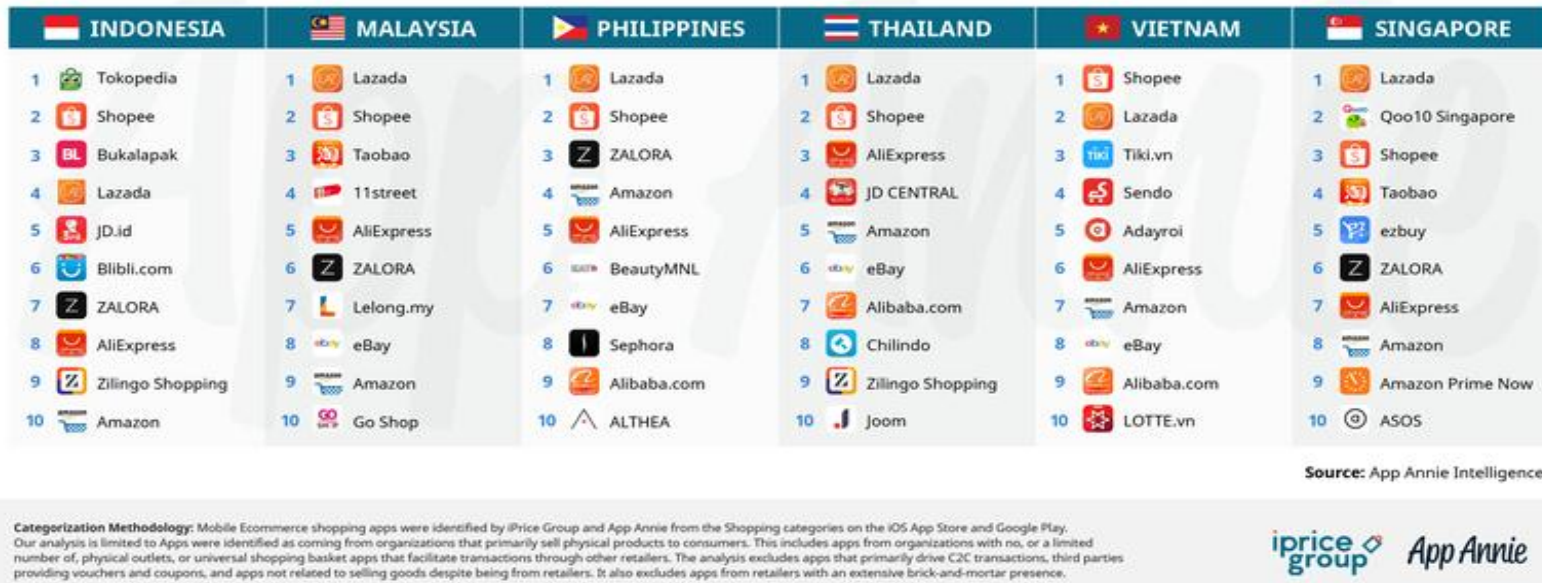

Source:https://en.wikipedia.org/wiki/Ecommerce_in_Southeast_Asia\#/media/File:2_Mobile_Ap p_(Monthly_Acitve_Users)_-_AppAnnie_x_iPrice.png

\section{Picture 2. Asian Ecommerce Users}


From the data above, it can be seen that online shopping is currently rife and is starting to become a trend in the world community. Given the statistics above, it's quite clear that Indonesia, the Philippines, Vietnam, Malaysia, Thailand and Singapore are the most promising for the Internet market in Southeast Asia. Therefore, if we are startup looking to attack your neighbors, look at key markets. For startups from all regions not only competing in their own local market but also looking to the regions to do battle. As such, it is more important than ever before to get a good picture of the market and understand the total size of the Internet \& e-commerce market penetration throughout the region. And in Indonesia the 5 highest e commerce or the most visited by Indonesian people are Tokopedia, Shopee, Bukalapak, Lazada and Jd.id.

Based on the description above, it can be seen that e-commerce is one of the innovations in technology that can be used as a strategy by entrepreneurs in marketing their products so that increasing sales volume can be obtained, because online shopping trends are currently rife in various countries in the world. Through this research we want to know whether the use of e commerce as innovation in sales strategies can increase the sales of products of entrepreneurs in the city of Bandung?

\section{LITERATURE REVIEW}

According to Kotler (2008), online marketing is a company's effort to market products and services and build relationships with customers through internet media. Online marketing is an application of the internet and related digital technologies to achieve marketing objectives, these technological technologies such as internet media, cables, satellites, hardware, software needed for internet marketing purposes.

\section{E-Commerce}

According to Sutabri (2012), E-commerce is the spread, purchase, sale, marketing of goods and services through electronic systems such as the internet or television, WWW, or other computer networks. E-commerce can involve electronic fund transfers, electronic data exchanges, automated inventory systems, and automated data collection systems. So it can be said that E-commerce is a marketing of goods or services through information systems that utilize internet technology.

Besides having benefits for companies, according to Sutarman (2009) ecommerce also has benefits for consumers, namely:

1. Allow customers to shop or do other transactions 24 hours wherever they are, no need to visit locations and save time.

2. Information can be obtained from various websites and can be compared in price and quality.

3. Enables consumers to interact with the electronic community and to exchange ideas and compare experiences.

Some of the benefits of $\mathrm{E}$ commerce for companies and consumers in http://www.pengahamanku.net/2016/06/pengahaman-e-commerce-sum-umum-dan-bennya.html include the following:

Some of the benefits that companies can get from e-commerce, including: 
1. Open all the time. Like e-commerce sites or websites that can operate at any time 24 hours a day and of course every day. It can be concluded that this can increase the number of consumers and orders received will increase.

2. Geographical or global reach. Physical stores will certainly be limited by geographical area. By using e-commerce, all corners of the world can be said to be a region for doing business. Because with e-commerce the company can run a business with a wider range.

3. Can get consumers through searching the internet. E-commerce sites or web companies can be found by consumers if they search for them on the internet and of course this will be one of the benefits that can be obtained by companies in doing business because new customers will arrive.

4. Promotion costs are relatively low. Another benefit that can be obtained from ecommerce is the relatively low promotion costs. Surely something like this will be one of the advantages for companies in promoting their products to consumers.

5. Looking for products to be faster and more accurate. For example on e-commerce websites or web sites, consumer companies can search for products by clicking on catalogs or menu buttons provided on their websites or using a search box so that consumers can find the product they want.

6. Can provide accurate and up-to-date information. Of course information will be more complete and easier to convey to consumers. Usually this information contains specifications regarding the products sold by the company. Information can also be updated at any time if there is a notification or new explanation about the products sold to consumers.

\section{E-Commerce Classification}

The common denominator of E-Commerce is that it is based on the nature of the transaction. According to Kenneth C. Laudon, Jane P. Laudon (2008: 63) and I Putu Agus (2015; 11) types the following can immediately be distinguished:

1. Business to business (B2B), is an e-commerce model where the business person is a company, so the transaction process and its interactions are between one company and another company (suppliers and retailers) Examples of this e-commerce model are several e-banking sites that serve transactions between companies.

2. Business to Consumer (B2C), is an e-commerce model where business people directly involve the seller (e-commerce service provider) with individual buyers or buyers. An example is airasia.com.

3. Consumer to Consumer (C2C), is an e-commerce model where individuals or individuals as sellers interact and transact directly with other individuals as buyers. The concept of e-commerce of this type is widely used in online auction sites or online auctions. An example is e-bay.com.

4. Consumer to Business (C2B), is an e-commerce model where consumers notify goods or services they need, then some companies will try to offer their services to meet these needs. An example is booking.com.

\section{Advantages of E-Commerce}

The advantages that can be obtained from e-commerce for organizations or companies according to Sutarman (2009) are: 
1. Expanding market place to national and international markets.

2. Save the cost of making, processing, distributing, storing and searching for information using paper.

3. Faster information access.

Access information faster. Besides having benefits for companies, according to Sutarman (2009) e-commerce also has benefits for consumers, namely:

1. Allow customers to shop or do other transactions 24 hours wherever they are, no need to visit locations and save time.

2. Information can be obtained from various websites and can be compared in price and quality.

3. Enables consumers to interact with the electronic community and to exchange ideas and compare experiences.

\section{Innovation}

According to Zimmerer in Suryana (2017) Innovation is the ability to apply creative solutions to problems and create opportunities to improve or enrich human life. Innovating for an entrepreneur is the key to success. Innovation is an entrepreneur's action to achieve success in competition.

According to Suryana (2017), mentioning innovation has several important meanings which include the following matters:

1. Innovation as Renewal (Innovation as Novelty)

In essence, innovation is a renewal or novelty that generates new added value for its users. The object of innovation is the added value of a product, or process, or service. Innovation is always expressed in the form of technological solutions that are better accepted by society. Novelty is a consequence of the practical implementation of innovation. The key parameter of innovation is added value for users.

2. Innovation as Change

Innovation is change, where change can be in the form of transformation, diffusion that results in change. Innovation begins with a new process to produce new objects.

3. Innovation as Excellence (Innovation as Advantage) Innovation is excellence, which means we create excellence in a new form. Innovation can take many forms, such as product, process, method, technology and management innovation. In management, innovation refers to the creation of new forms of excellence.

\section{MARKETING STRATEGY}

\section{Understanding of Marketing Strategy}

According to Kotler (2008), marketing strategy is a marketing logic where business units hope to create value and benefit from its relationship with consumers. According to Kotler (2008), in an effort to get consumer satisfaction in the midst of competition, companies must first understand what their customers' needs and desires are. A company realizes that it cannot fulfill the desires of very different consumers. As is well known that every person who establishes a company, of course aims to produce an item which then the goods are not just stored in a warehouse, but must be sold to consumers to obtain compensation in the form of profit. Marketing strategies in a company must be dynamic along with changes in products, markets and 
competitors and be able to follow the product life cycle. In its marketing strategy, SMEs use ecommerce systems to reach their guests or customers both locally and globally.

\section{Sales}

Moekijat (2000) states that selling is an activity aimed at finding buyers, influencing and giving instructions so that buyers can adjust their needs to the products offered and enter into agreements regarding prices that are beneficial to both parties. Furthermore, according to Kotler (2008) Sales is also a managerial social process where individuals and groups get what they need and want, create, offer, and exchange products of value.

Sales activities are the company's main income because if the activities of selling products or services are not managed properly, it can directly harm the company. This can be caused by the expected sales targets not being achieved and income will be reduced.

Sales according to Buchari (2007) is a process of planning, directing, and supervising sellers (Personal Selling) at a company. According to Basu (2008: 18) sales is a whole system of activities that are shown to plan, determine prices, promote and distribute goods, services, ideas to the target market in order to achieve organizational goals. Choosing someone to be a seller in a company is very dependent on the work to be done, the state of the product, the intended consumer and so on. From some of the definitions above, it appears clearly that the sale is a number of activities that occur as a result of the movement of goods or services from the hands of producers to the hands of consumers and includes all activities before and after the removal of the goods or services. MSMEs use e-commerce systems to increase sales of their products.

\section{Sales Volume}

From an explanation of sales, sales are always associated with sales terms and sales volume. The size of the sale is influenced by the number of products sold. Sales Volume is the total sales obtained from commodities traded within a certain period. (Downes, John, Jordan Elliot Goodman,2000).

Sales volume is the number of sales that were achieved or wanted to be achieved by a company in a certain period. Based on the above meanings, it can be concluded that the sales volume is the result of sales activities carried out by the company in an effort to achieve the goal of maximizing profit.

\section{Research Methods}

The method used in this research is descriptive verification method. namely a method that aims to describe the state of the company based on real factors in something being investigated where the data collected is first organized, explained, and then analyzed.

Descriptive research is research that aims to describe the nature or characteristics of a particular phenomenon. (M. Iqbal Hasan, 2006). Verification research is research conducted to test hypotheses using statistical calculations using simple linear regression. In this research there are two variables to be studied are e commerce and sales volume. The population of this research is food and beverage MSMEs that use e-commerce. The samples are taken using purposive sampling and a sample of 85 entrepreneurs in the city of Bandung is obtained. 


\section{FINDING AND DISCUSSION}

Based on the results of research conducted in the field, it was found that by using ecommerce in marketing products sold by entrepreneurs, it could help increase sales of their products. As for the data obtained from the field are as follows:

Table 1. Increase in Turnover after implementing e-commerce

\begin{tabular}{|c|c|}
\hline Increase in Turnover & \% increase \\
\hline Under $0 \%$ & $2 \%$ \\
\hline $0 \%$ to $10 \%$ & $7 \%$ \\
\hline $11 \%$ to $20 \%$ & $9 \%$ \\
\hline $21 \%$ to $30 \%$ & $9 \%$ \\
\hline $31 \%$ to $40 \%$ & $20 \%$ \\
\hline $41 \%$ to $50 \%$ & $33 \%$ \\
\hline $51 \%$ to $60 \%$ & $4 \%$ \\
\hline Over $60 \%$ & $15 \%$ \\
\hline TOTAL & $100 \%$ \\
\hline
\end{tabular}

Source: Primary data processed

From the above data it can be seen that the largest increase is as much as $33 \%$ of respondents who experienced an increase in turnover between $41 \%$ to $50 \%$. while $15 \%$ of respondents experienced a turnover increase from $51 \%$ to $60 \%$. This is clearly seen that by using e-commerce can increase the turnover of businesses in the city of Bandung, especially businesses in the field of food and beverages.

\section{Regression Analysis}

Table 2 Regression Coefficient Coefficients $^{\mathrm{a}}$

\begin{tabular}{|c|c|c|c|c|c|c|c|}
\hline \multirow[b]{2}{*}{ Model } & \multicolumn{2}{|c|}{$\begin{array}{l}\text { Unstandardized } \\
\text { Coefficients }\end{array}$} & \multirow{2}{*}{$\begin{array}{c}\begin{array}{c}\text { Standardized } \\
\text { Coefficients }\end{array} \\
\text { Beta }\end{array}$} & \multirow[b]{2}{*}{$\mathrm{t}$} & \multirow[b]{2}{*}{ Sig. } & \multicolumn{2}{|c|}{$\begin{array}{c}\text { Collinearity } \\
\text { Statistics }\end{array}$} \\
\hline & $\mathrm{B}$ & Std. Error & & & & Tolerance & VIF \\
\hline $1 \quad$ (Constant) & .540 & .275 & & 1.962 & .053 & & \\
\hline $\mathrm{X}$ & .835 & .081 & .749 & 10.288 & .000 & 1.000 & 1.000 \\
\hline
\end{tabular}

a. Dependent Variable: Y

Source: results of data processing using SPSS

The regression model is shown in table 6, so we get a regression model:

$$
Y=0.540+0.835 X
$$

Which means that without the presence of e-commerce, sales volume has a value of 0.540 and each increase in e-commerce performance by 1 unit will increase sales volume by 1,375 units. 


\section{Correlation Analysis}

Correlations are displayed in the data processing results in the following table:

Table 3. Model Summary

Model Summary ${ }^{b}$

\begin{tabular}{|l|c|r|r|r|r|}
\hline Model & R & R Square & $\begin{array}{c}\text { Adjusted R } \\
\text { Square }\end{array}$ & $\begin{array}{c}\text { Std. Error of } \\
\text { the Estimate }\end{array}$ & $\begin{array}{c}\text { Durbin- } \\
\text { Watson }\end{array}$ \\
\hline 1 & $.749^{\mathrm{a}}$ & .560 & .555 & .44799 & 1.970 \\
\hline
\end{tabular}

a. Predictors: (Constant), $\mathrm{X}$

b. Dependent Variable: Y

Source: results of data processing using SPSS

Based on the table above, the correlation is shown by the $\mathrm{R}$ value of 0.749 which means that e-commerce and sales volume have a strong relationship with the category based on the interpretation shown in table 2. The coefficient of determination (KD) is shown in table 7 on the $\mathrm{R}$ square value, which is 0.56 or $56 \%$. This value implies that e-commerce affects sales volume by $56 \%$, while the remaining $44 \%$ is influenced by other factors not calculated in this study.

\section{CONCLUSION AND SUGGESTION}

Based on the results of the above research, technological developments bring enormous changes in various aspects of life, one of which is in the business world. The impact of technology, especially the use of e-commerce as one of the technological innovations used by entrepreneurs or entrepreneurs in the city of Bandung, especially those engaged in food and beverage business, is the increase in turnover obtained by entrepreneurs after using e-commerce. The advice that we can convey is to conduct further research to more entrepreneurs or entrepreneurs so that overall data can be obtained about entrepreneurs in various levels and kinds.

\section{REFERENCE}

Ali Z. 2008. Kiat jitu membuat website tanpa modal. Elekmedia Komputindo. Jakarta

Agus, I Putu., 2015, E-commerce, E-business dan Mobile Commerce, Informatika, Bandung.

Alma,H.Buchari, dan Donni Juni Priansa, Manajemen Bisnis Syariah, Alfabeta, Bandung, 2014.

Downes, John, Jordan Ellot Goodman, Kamus Istilah keuangan dan investasi, Kelompok Gramedia, Jakarta, 2000.

Fontana, Avanti .2011. Innovate We Can, Manajemen Inovasi dan Penciptaan Nilai Individu, organisasi, masyarakat. Cipta Inovasi Sejahtera, Jakarta

Kotler, Philip, 2008, Prinsip-Prinsip Pemasaran, Jilid 1, Edisi 12, Erlangga, Jakarta Moekijat, Kamus Manajemen, CV.Mandar Maju, Bandung, 2000. 
Laudon, Kenneth C., dan Laudon, Jane P., 2008, Sistem Informasi Manajemen, Salemba Empat, Jakarta.

Sutarman, 2009, Pengantar Teknologi Informasi, PT. Bumi Aksara, Jakarta.

Suryana.(2017).Kewirausahaan : Kiat dan Proses menuju sukses. Jakarta : Salemba Empat M. Iqbal Hasan, 2006. Pokok-pokok Materi Metode penelitian dan Aplikasinya, PT Ghalia. Jakarta

Adiwihardja ,Cep,2016.Ecommerce Sebagai Model Inovasi Teknologi Strategi Enterpreneur Menurut Preferensi Pengguna Pada Jakartanotebook.com, BINA INSANI ICT JOURNAL, Vol.3, No.1, Juni 2016, 154 - 163 ISSN: 2355-3421 (Print) ISSN: 25279777 (Online) 